\title{
Staphylococcus aureus: Vieja bacteria con nuevos trucos
}

D espués de más de 120 años desde su descubrimiento, Staphylococcus aureus continua evadiendo a los médicos clínicos, originando más preguntas que nunca. Los mecanismos patogénicos de esta bacteria, se deben, en parte, al amplio repertorio de factores de virulencia, a la tendencia a invadir tejidos y el endotelio vascular, y a su maleabilidad para integrar factores genéticos que confieren tanto virulencia como resistencia antimicrobiana, a la vez evadiendo la respuesta inmune del hospedero ${ }^{1-3}$. La evolución existosa de $S$. aureus resistente a meticilina (SAMR) es quizás una premonición de la epidemia mundial a la que nos enfrentamos así como de los desafíos futuros $^{4-6}$. A pesar de que se ha descrito ampliamente que SAMR es responsable de infecciones nosocomiales hospitalarias, no fue hasta que se empezaron a reportar infecciones por SAMR con clones únicos en pacientes previamente sanos sin factores de riesgo, que se empezó a reconocer la creciente prevalencia de estas infecciones en la comunidad ${ }^{7-11}$. Gracias a estudios poblacionales, el Centro de Control y Prevención de Enfermedades (CDC) de los Estados Unidos de América (EUA), ha identificado a SAMR como un problema mayor de salud pública. El CDC ha estimado una incidencia de casos de enfermedad invasora causados por SAMR de 31,8 por 100.000 personas, ocasionando 18.650 muertes tan solo en el año $2005^{12}$. Desde la primera comunicación de infecciones por SAMR adquirido en la comunidad en niños, este tipo de infecciones continúa afectado de una manera desproporcionada a la población pediátrica ${ }^{9,12,13}$. con frecuencias que varían entre $30 \%$ y $70 \%$ dentro de los hospitales pediátricos de EUA, dependiendo del área geográfica $^{14-16}$. Hay datos que sugieren que las cepas de SAMR adquirido en la comunidad, así como los factores de riesgo de infección, podrían ser diferentes en niños y adultos ${ }^{17}$. La gran versatilidad del SAMR adquirido en la comunidad ha permitido que haya surgido como un patógeno bacteriano de primera importancia, causando un espectro diverso de enfermedad que varía desde las frecuentes infecciones de piel y tejidos blandos y enfermedades mediadas por toxinas, a la enfermedad invasora e infecciones supuradas con tasas de mortalidad significativamente superiores en pacientes con sepsis e enfermedad diseminada ${ }^{18}$. No es, por tanto, una sorpresa que la magnitud creciente de las infecciones por SAMR adquirido en la comunidad, su virulencia, así como los cambios observados en su epidemiología hayan sido comunicados a nivel mundial en la última década ${ }^{19}$.

En esta edición de Revista Chilena de Infectología, diferentes autores resaltan la cambiante evolución clínica de las infecciones causadas por SAMR adquirido en la comunidad en Argentina y Uruguay, así como las correlaciones encontradas con el uso de antimicrobianos y el desarrollo emergente de patrones de resistencia. Ambos estudios demuestran que más de $60 \%$ de cepas de $S$. aureus son resistentes a meticilina y que el cuadro de presentación clínico más frecuente son los abscesos de piel y tejidos blandos. Paganini y cols, realizaron un estudio observacional, prospectivo, multicéntrico, en niños mayores de un mes de edad que acudieron al hospital en busca de atención medica. Ellos compararon las infecciones por el SAMR adquirido en la comunidad entre pacientes previamente sanos y niños con enfermedad de base o factores de riesgo de infección nosocomial. De acuerdo con otros estudios que han documentado el impacto de SAMR adquirido en la comunidad en niños que han estado expuestos al medio sanitario ${ }^{20,21}$, el tipo de infección más frecuente en ambos grupos fue el de piel y tejidos blandos, aunque las tasas más altas de infección se documentaron en niños que no habían estado expuestos al ambiente sanitario ni tenían factores de riesgo. Las tasas de bacteriemia, sepsis, y mortalidad fueron también similares en ambos grupos. Hay que destacar que el grupo de niños previamente sanos necesitó con mayor frecuencia procedimientos quirúrgicos en comparación con el grupo con factores de riesgo de infección hospitalaria o enfermedad subyacente. El grupo de niños con factores de riego tuvo niveles de resistencias superiores a rifampicina, cotrimoxazol, y clindamicina. Aunque se pensó que las cepas de SAMR adquiridas en la comunidad eran similares en ambos grupos, no se realizaron estudios moleculares que confirmaran esta observación, lo que podría explicar, en parte, algunas de las diferencias observadas. Se observó una gran discordancia ( $>50 \%$ ) en ambos grupos en cuanto al uso de tratamiento antimicrobiano empírico y el patógeno aislado y un retraso de 72-96 horas antes de que se instaurara el tratamiento antimicrobiano adecuado. Estas observaciones subrayan tanto la importancia de la elección adecuada del tratamiento empírico como la necesidad de métodos de diagnostico más sensibles y rápidos. Por otra parte, Telechea y cols. realizaron un estudio retrospectivo observacional desde el año 2001 al 2006 con el fin de documentar el uso de antimicrobianos en niños internados en un hospital pediátrico de Uruguay. Ellos evaluaron las susceptibilidades in vitro de cepas de $S$. aureus que se obtuvieron de infecciones anatómicamente localizadas en sitios estériles así como de abscesos cutáneos y de tejidos blandos. Los autores 
describen la implementación de guías nacionales sobre el uso empírico de antimicrobianos establecidas desde el 2004 en respuesta a las tasas crecientes de infecciones por SAMR, pero el tratamiento empírico recomendado en base al cuadro clínico no fue claro y los autores no proveen datos sobre si se detectó posibles diferencias epidemiológicas entre el período post implementación de las guías. Como era de esperar, el uso de clindamicina, vancomicina y cotrimoxazol aumentó durante el periodo del estudio. Aunque la proporción de $S$. aureus sensibles a oxacilina disminuyó, el uso de ceftriaxona y cefotaxima aumentó. El aumento en el uso de clindamicina durante la duración del estudio coincidió con el aumento tanto en la sensibilidad de eritromicina como de clindamicina. En el período del 2004 al 2006, detectaron una disminución de resistencia inducible a clindamicina, evaluadas con el D-test, aunque las tasas de resistencia inducible a clindamicina fueron elevadas, de hasta $21 \%$. A pesar de que el impacto real de la resistencia inducible a clindamicina no se ha documentado adecuadamente, la mayoría de los expertos no recomiendan el uso empírico de clindamicina en áreas donde el laboratorio local de microbiología demuestra que la proporcion de aislados de SAMR resistentes a clindamicina supera el 10\%.

La definición de lo que se considera infecciones por SAMR adquirido en la comunidad es cada vez más discutible, por lo cual es importante que continúe la vigilancia de este tipo de infecciones a nivel local, incluyendo estudios epidemiológicos y de cuadros clínicos de presentación, cultivos apropiados de SAMR, técnicas moleculares que permitan precisar el genotipo de SAMR, y determinación de las susceptibilidades antimicrobianas ${ }^{22,23}$. El CDC ha definido a las infecciones por SAMR adquirido en la comunidad como el aislamiento de una cepa de SAMR de pacientes de forma extra-hospitalaria o en las primeras 48 horas de la hospitalización sin que existan catéteres intravenosos, hospitalizaciones previas, o historia conocida de infección o colonización por $\mathrm{SAMR}^{9,24}$. Las técnicas de diagnóstico molecular se han usado también para clasificar las cepas de SAMR adquiridas en la comunidad. La electroforesis de campo pulsado ha permitido identificar y clasificar los clones USA 300 y 400, que corresponden a la secuencia multilocus tipos 8 y 1 , respectivamente las cuales son las cepas predominantes de SAMR asociadas con la transmisión en la comunidad ${ }^{25}$. Las cepas de SAMR que contienen el gen mecA en el complejo cromosómico del casette estafilocóccico mec (SCCmec) o cepas que tienen ciertos factores de virulencia como el Panton
Valentine Leukocidin- PVL o elementos genéticos como el catabolito móvil de la arginina (ACME) se han usado para definir qué cepas de SAMR son adquiridas en la comunidad y cuáles no ${ }^{25-29}$. Por último, en comparación con las cepas nosocomiales de SAMR, las cepas de SAMR adquiridas en la comunidad han demostrado ser sensibles a la mayoria de clases de antimicrobianos (excepto a los $\beta$-lactámicos y macrólidos) incluyendo clindamicina, cotrimoxazol, fluoroquinolonas y tetraciclinas.

Pero son cada vez menos claras las diferencias entre lo que se considera un aislado ‘típico' nosocomial de SAMR y un SAMR adquirido en la comunidad. El hecho de que es más frecuente encontrar excepciones a las definiciones epidemiológicas de las infecciones por SAMR adquirido en la comunidad, de la sensibilidad a los antimicrobianos de SAMR y de las definiciones moleculares de las infecciones por SAMR, hace que las posibilidades de tener una definición única y global sean poco probable. El descubrimiento de nuevos factores de virulencia ${ }^{30-32}$, aislamiento de cepas de SAMR adquirido en la comunidad en el hospital ${ }^{33-36}$ y cambios en las sensibilidades a vancomicina y clindamicina ${ }^{14,37,38}$ y nuevos antimicrobianos anti-estafilocóccicos ${ }^{39-41}$ continúan siendo un reto, tanto para los médicos clínicos como para los investigadores de ciencia básica. Muchas preguntas claves para el diagnóstico y manejo clínico de infecciones por SAMR continúan sin respuesta y subrayan la necesidad urgente de estudios que aporten los datos suficientes para decidir cuál es el tratamiento óptimo en casos de infecciones invasoras, el manejo de infecciones cutáneas y de tejidos blandos, el establecimiento de estrategias de prevención y vigilancia epidemiológica exitosas, así como estimular el desarrollo de nuevos antimicrobianos y vacunas. Mientras tanto, con el propósito de guiar a los médicos clínicos, el CDC ha publicado un resumen de estrategias sobre el manejo clínico en pacientes infectados por SAMR adquirido en la comunidad (http://www.cdc.gov/ncidod/dhqp/ar_mrsa_ca_04meeting.html) y la Academia Americana de Pediatría ha implementado un algoritmo para el manejo de niños en los que se sospecha infección por SAMR adquirido en la comunidad.

Monica I. Ardura, DO Assistant Professor of Pediatrics, Division of Pediatric Infectious Diseases University of Texas Southwestern Medical Center, Dallas, Texas, USA 


\section{Staphylococcus aureus: Old bug with new tricks}

S taphylococcus aureus: Now 120 years after it was first discovered, Staphylococcus aureus continues to elude clinicians, perhaps raising more questions than ever before. The bacterium's pathogenicity stems in part from its repertoire of virulence factors, proclivity for tissue and endovascular invasion, and its malleability in integrating genetic elements that confer virulence and antimicrobial resistance, while simultaneously evading the host's immune response $\mathrm{e}^{1-3}$. The successful evolutionary history of methicillin-resistant $S$. aureus (MRSA) is perhaps a forewarning of our current global epidemic and future challenges ${ }^{4-6}$. Though MRSA was a well-known cause of health care-associated (HCA) infections, it was not until reports of infection with unique clones of MRSA in otherwise healthy subjects without typical HCA risk factors, that the escalating prevalence of community-associated (CA) MRSA began to be recognized ${ }^{7-11}$. The Centers for Disease Control and Prevention (CDC) of the United States has identified MRSA as a major public health problem in a populationbased surveillance study, estimating the incidence rate for invasive MRSA infections in the United States to be 31.8 per 100,000 persons, leading to 18,650 deaths in 2005 alone $^{12}$. Since first reported in children, CAMRSA infections continue to disproportionately affect the pediatric population ${ }^{9,12,13}$ with frequencies varying geographically from 30 to $70 \%$ across pediatric hospitals in the US ${ }^{14-16}$. Data suggest that CA-MRSA isolates and risk factors for infection may be different in children than adults ${ }^{17}$. The versatility of CA-MRSA has allowed it to emerge as a major bacterial pathogen causing a diverse spectrum of clinical illnesses ranging from the more common skin and soft-tissue infections, toxinmediated diseases to invasive, suppurative infections, with the highest mortality seen in those patients with sepsis and disseminated disease ${ }^{18}$. It is not surprising that during the last decade, the increasing magnitude of CA-MRSA disease burden, virulence, and its changing epidemiology has now been reported worldwide ${ }^{19}$.

In this issue of the Revista Chilena de Infectología, authors highlight the evolving clinical epidemiology of CA-MRSA infections in Argentina and Uruguay, along with corresponding antimicrobial usage and emerging resistance patterns. Both studies demonstrate that greater than $60 \%$ of $S$. aureus isolates are methicillin-resistant and skin and soft-tissue abscesses are the most common clinical presentations. Paganini et al, performed a multi-center, prospective observational study in children over 1 month of age seeking medical attention, comparing CA-MRSA infections in previously healthy subjects to children with known underlying medical conditions or HCA risk factors.
Similar to other studies assessing the impact of CA-MRSA in children with health care exposure ${ }^{20,21}$, the majority of cases in both groups were skin and soft-tissue infections, though the rates were highest children without HCA risk factors. The rates of bacteremia, sepsis, and overall mortality were also similar in both groups. Interestingly, previously healthy children required more surgical procedures than children with underlying medical conditions or HCA risk factors. Children with HCA risk factors had higher levels of rifampin, trimethoprim/sulfamethoxazole, and clindamycin resistance. Although CA-MRSA strains were thought to be similar in both groups, no molecular analyses were performed on the isolates to confirm this observation and may explain some of the differences observed. There was a high discordance $(>50 \%)$ in both groups between empiric antibiotic therapy and the pathogen isolated and delay of 72-96 hours before appropriate antimicrobial therapy was started. These observations underscore not only the importance of empiric antibiotic choices, but the need for improved, rapid diagnostic methodologies. Telechea and colleagues performed a retrospective observational study to assess antimicrobial usage in hospitalized children at a pediatric hospital in Uruguay from 2001-2006. They evaluated the in vitro susceptibilities of the $S$. aureus isolates obtained from sterile body sites and skin/soft tissue abscesses during the same study period. The authors comment that new national empiric antibiotic guidelines were established in 2004 in response to the increasing rates of MRSA, however the empiric antibiotics recommended depending on the clinical syndrome are unclear and any epidemiologic differences that may have been noted before or after the guidelines were implemented are lacking. As expected, the use of clindamycin, vancomycin, and trimethoprim/ sulfamethoxazole increased during the study period. Although oxacillin susceptibility of $S$. aureus isolates decreased, use of ceftriaxone and cefotaxime increased. The increased use of clindamycin during the study period coincided with an increase in both erythromycin and clindamycin susceptibility. From 2004-6, there was a decrease in inducible clindamycin resistance, as evaluated by D-zone testing, although the overall rate was still high at $21 \%$. Though the actual impact of inducible clindamycin resistance is not well described, most experts would not recommend empiric clindamycin therapy in areas where local microbiology laboratory results demonstrate that the proportion of CA-MRSA isolates resistant to clindamycin are greater than $10 \%$.

Continued surveillance of CA-MRSA infections 
locally, including clinical epidemiology and disease syndromes, MRSA microbiology cultures and molecular genotypic information, and antimicrobial susceptibility testing are even more important as the definition of what is considered a CA-MRSA infection becomes more contentious $^{22,23}$. CA-MRSA infections have been defined by the US Centers for Disease Control and Prevention as the isolation of MRSA from a subject in the outpatient setting or within 48 hours of admission in hospitalized patients with no indwelling catheters, prior hospitalization, or known history of previous MRSA infection or colonization ${ }^{9,24}$. Molecular characteristics have also been used to classify an MRSA isolate as acquired in the community. Pulse-field gel electrophoresis types USA 300 and 400, corresponding to multilocus sequence types 8 and 1, respectively, have been the predominant MRSA types associated with community transmission ${ }^{25}$. MRSA strains carrying the mecA gene on the staphylococcal cassette chromosome mec (SCCmec) gene complex or isolates containing certain virulence genes such as PVL or genetic elements such as arginine catabolic mobile element (ACME) have also been used to define CA-MRSA isolates $^{25-29}$. Lastly, unlike HCA-MRSA, CA-MRSA strains have typically demonstrated susceptibility to most classes of antimicrobial agents (other than $\beta$-lactams and macrolides) such as clindamycin, trimethoprim/sulfamethoxazole, fluoroquinolones, and tetracyclines.

However, differences between what were considered 'typical' HCA and CA-MRSA isolates are becoming less distinct. Growing exceptions to the epidemiologic, antimicrobial susceptibility, and molecular definitions of CA-MRSA infections, make it less likely that a single, comprehensive definition is achievable. Discovery of new virulence determinants $\mathrm{s}^{30-32}$, findings of CA-MRSA isolates in hospital settings $\mathrm{s}^{33-36}$, and changing antimicrobial susceptibilities to vancomycin and clindamycin ${ }^{14,37,38}$ and newer anti-staphylococcal antibiotics ${ }^{39-41}$ continue to challenge clinicians and researchers alike. Many key clinical questions also remain unanswered and highlight the urgent need for studies to provide data needed to guide the optimal treatment of invasive disease, management of sknd soft-tissue infections, and performance of successful prevention and surveillance strategies, as well as stimulating antimicrobial new drug and vaccine development. In the interim, in an effort to help guide clinicians, the CDC has published a summary of strategies for clinical management of MRSA in the community (http://www. cdc.gov/ncidod/dhqp/ar_mrsa_ca_04meeting.html) and the American Academy of Pediatrics has also formulated a suggested algorithm for managing children with suspected CA-MRSA infections.

\section{Monica I. Ardura, DO Assistant Professor of Pediatrics, Division of Pediatric Infectious Diseases University of Texas Southwestern Medical Center, Dallas, Texas, USA}

\section{Referencias}

1.- Lowy F D. Staphylococcus aureus infections. N Engl J Med 1998; 339 (8): 520-32.

2.- Foster T J. Immune evasion by staphylococci. Nat Rev Microbiol 2005; 3 (12): 948-58.

3.- DeLeo F R, Diep B A, Otto M. Host defense and pathogenesis in Staphylococcus aureus infections. Infect Dis Clin North Am 2009; 23 (1): 17-34.

4.- Lowy F D. Antimicrobial resistance: the example of Staphylococcus aureus. J Clin Invest 2003; 111 (9): 1265-73.

5.- Enright M C, Robinson D A, Randle G, Feil E J, Grundmann H. The evolutionary history of methicillin-resistant Staphylococcus aureus (MRSA). Proc Natl Acad Sci USA 2002; 99 (11): 7687-92.

6.- Stewart G T, Holt R J. Evolution of natural resistance to the newer penicillins. Br Med J 1963; 1 (5326): 308-11.

7.- From the Centers for Disease Control and Prevention. Four pediatric deaths from communityacquired methicillin-resistant Staphylococcus aureus-Minnesota and North Dakota, 1997-1999. Jama 1999; 282 (12): 1123-5.
8.- Herold B C, Immergluck L C, Maranan M C, Lauderdale D S, Gaskin R E, Boyle-Vavra S, et al. Community-acquired methicillin-resistant Staphylococcus aureus in children with no identified predisposing risk. JAMA 1998 25; 279 (8): 593-8.

9.- Fridkin S K, et al. Methicillin-resistant Staphylococcus aureus disease in three communities. N Engl J Med 2005; 352 (14): 1436-44.

10.- Zetola N, Francis J S, Nuermberger E L, Bishai W R. Community-acquired meticillinresistant Staphylococcus aureus: an emerging threat. Lancet Infect Dis 2005; 5 (5): 275-86. Review.

11.- Suggs A H, Maranan M C, Boyle-Vavra S, Daum R S. Methicillin-resistant and borderline methicillin-resistant asymptomatic Staphylococcus aureus colonization in children without identifiable risk factors. Pediatr Infect Dis J 1999; 18(5): 410-4.

12.- Klevens R M, Morrison M A, Nadle J, Petit S, Gershman K, Ray S, et al. Active Bacterial Core surveillance (ABCs) MRSA Investigators. Invasive methicillin-resistant Staphylococcus aureus infections in the United States. JAMA
2007; 298 (15): 1763-71.

13.- Li F, Ayers T L, Park S Y, DeWolfe Miller F, MacFadden R, Nakata M, et al. Isolate removal methods and methicillin-resistant Staphylococcus aureus surveillance. Emerg Infect Dis 2005; 11 (10): 1552-7.

14.- Kaplan S L, Hulten K G, González B E, Hammerman W A, Lamberth L, Versalovic J, et al. Three-year surveillance of communityacquired Staphylococcus aureus infections in children. Clin Infect Dis 2005; 40 (12): 1785-91. Epub 2005 May 6.

15.- Buckingham S C, McDougal L K, Cathey L D, Comeaux K, Craig A S, Fridkin S $\mathrm{K}$, et al. Emergence of community-associated methicillin-resistant Staphylococcus aureus at a Memphis, Tennessee Children's Hospital. Pediatr Infect Dis J 2004; 23 (7): 619-24.

16.- Purcell K, Fergie J E. Exponential increase in community-acquired methicillin-resistant Staphylococcus aureus infections in South Texas children. Pediatr Infect Dis J 2002; 21 (10): 988-9.

17.- David M Z, et al. Contrasting pediatric and adult methicillin-resistant Staphylococcus aureus isolates. Emerg Infect Dis 2006; 12 (4): 631-7. 
18.- Kaplan S. Community-acquired methicillinresistant Staphylococcus aureus infections in children. Semin Pediatr Infect Dis 2006; 17: 113-9.

19.- Vandenesch F, et al. Community-acquired methicillin-resistant Staphylococcus aureus carrying Panton-Valentine leukocidin genes: worldwide emergence. Emerg Infect Dis 2003; 9 (8): 978-84.

20.- Hulten K G, KS, González B E, Hammerman W A, Lamberth L B, Versalovic J, Mason E O. Three-year surveillance of community onset health-care associated Staphylococcus aureus infections in children. Pediatr Infect Dis J 2006; 25: $349-53$.

21.- Zaoutis T E, T P, Chu J, Abrams T, Dul M, Kim J, McGowan K L, et al. Clinical and molecular epidemiology of community-acquired methici1lin-resistant Staphylococcus aureus infections among children with risk factors for health-care associated infection, 2001-2003. Pediatr Infect Dis J 2006; 25: 343-8.

22.- Gorwitz R J. A review of community-associated methicillin-resistant Staphylococcus aureus skin and soft tissue infections. Pediatr Infect Dis J 2008; 27 (1): 1-7.

23.- David M Z, Glikman D, Crawford S E, Peng $\mathrm{J}$, King $\mathrm{K} \mathrm{J}$, Hostetler M A, et al. What is community-associated methicillin-resistant Staphylococcus aureus? J Infect Dis 2008; 197 (9): 1235-43.

24.- Garner J S, Jarvis W R, Emori T G, Horan T C, Hughes J M. CDC definitions for nosocomial infections, 1988. Am J Infect Control. 1988 Jun; 16(3): 128-40. Erratum in: Am J Infect Control 1988; 16 (4): 177.

25.- McDougal L K, SC, Killgore G E, Chaitram J M, McAllister S K, Tenover FC. Pulsed-field gel electrophoresis typing of oxacillin-resistant Staphylococcus aureus isolates from the United States: establishing a national database. J Clin Microbiol 2003; 41: 5113-5120.

26.- Diep B A, Gill S R, Chang R F, Phan T H, Chen
J H, Davidson M G, et al. Complete genome sequence of USA300, an epidemic clone of community-acquired methicillin-resistant Staphylococcus aureus. Lancet 2006 M; 367 (9512): 731-9. Review.

27.- Ma X X, IT, Tiensasitorn C, et al. Novel type of staphylococcal cassette chromosome mec idenfitied in community-acquired methicillin-resistant Staphylococcus aureus strains. Antimicrob Agents Chemother 2002; 46: 1147-52.

28.- Baba T, Takeuchi F, Kuroda M, Yuzawa H, Aoki $\mathrm{K}$, Oguchi A, et al. Genome and virulence determinants of high virulence community-acquired MRSA. Lancet 2002; 359 (9320): 1819-27.

29. Naimi T S, LeDell K H, Como-Sabetti K, Borchardt S M, Boxrud D J, Etienne J, et al. Comparison of community- and health careassociated methicillin-resistant Staphylococcus aureus infection. JAMA 2003; 290 (22): 297684.

30.- Wang R, BK, Kretschmer D, Bach T H, Queck S Y, Li M, Kennedy A D, et al. Identification of novel cytolytic peptides as key virulence determinants for community-associated MRSA. Nat Med 2007; 13 (12): 1510-4.

31.- Bubeck Wardenburg J, BT, Otto M, DeLeo FR, Schneewind O. Poring over pores: alphahemolysin and Panton-Valentine leukocidin in Staphylococcus aureus pneumonia. Nat Med 2007; 13 (12): 1405-6.

32.- Bubeck Wardenburg J, P-BA, Otto M, Schneewind O, DeLeo FR. Panton-Valentine leukocidin is not a virulence determinant in murine models of community-associated methicillinresistant Staphylococcus aureus disease. J Infect Dis 2008; 198 (8): 1166-70.

33.- Healy C M, Hulten K G, Palazzi D L, Campbell J R, Baker C J. Emergence of new strains of methicillin-resistant Staphylococcus aureus in a neonatal intensive care unit. Clin Infect Dis. 2004; 39 (10): 1460-6. Epub 2004 Oct 27.

34.- Maree C L, Daum R S, Boyle-Vavra S, Matayoshi K, Miller L G. Community-associated methicillin-resistant Staphylococcus aureus isolates causing healthcare-associated infections. Emerg Infect Dis 2007 Feb; 13(2): 236-42.

35.- González B E, Rueda A M, Shelburne S A 3rd, Musher D M, Hamill RJ, Hulten K G. Community-associated strains of methicillinresistant Staphylococccus aureus as the cause of healthcare-associated infection. Infect Control Hosp Epidemiol 2006; 27 (10): 1051-6. Epub 2006 Sep 18

36.- Saiman L, O’Keefe M, Graham PL 3rd, Wu F, Saïd-Salim B, Kreiswirth B, et al Hospital transmission of community-acquired methicillin-resistant Staphylococcus aureus among postpartum women. Clin Infect Dis 2003; 37 (10): 1313-9. Epub 2003 Oct 17.

37.- Fridkin S K, Hageman J, McDougal L K, Mohammed J, Jarvis W R, Perl T M, et al; Vancomycin-Intermediate Staphylococcus aureus Epidemiology Study Group. Epidemiological and microbiological characterization of infections caused by Staphylococcus aureus with reduced susceptibility to vancomycin, United States, 1997-2001. Clin Infect Dis 2003; 36 (4): 429-39. Epub 2003 Jan 31.

38.- Mason E O, Lamberth L B, Hammerman W A, Hulten K G, Versalovic J, Kaplan S L. Vancomycin MICs for Staphylococcus aureus vary by detection method and have subtly increased in a pediatric population since 2005. J Clin Microbiol 2009; 47 (6): 1628-30. Epub 2009 Apr 29.

39.- Eltringham I. Mupirocin resistance and methicillin-resistant Staphylococcus aureus (MRSA). J Hosp Infect 1997; 35 (1): 1-8.

40. Tsiodras S, Gold H S, Sakoulas G, Eliopoulos G M, Wennersten C, Venkataraman L, et al. Linezolid resistance in a clinical isolate of Staphylococcus aureus. Lancet 2001; 358 (9277): 207-8.

41.- Skiest D. Treatment failure resulting from resistance of Staphylococcus aureus to daptomycin. J Clin Microbiol 2006; 44: 655-6. 